\title{
Recenzja „Rocznika Pedagogicznego”, t. 41, pod redakcją Marii Dudzikowej
}

\section{STRESZCZENIE}

Tekst jest prezentacją jednego z tomów „Rocznika Pedagogicznego”, czasopisma naukowego mającego duże znaczenie w ukazywaniu aktualnych problemów pedagogicznych. SŁowA KLUCzowe: pedagogika, „Rocznik Pedagogiczny”, wyzwolenie, kultura edukacji

Otwierając 40. jubileuszowy tom „Rocznika Pedagogicznego”, Redakcja apelowała do Czytelnika o zrozumienie trudnej dla pisma chwili. Wówczas to, na skutek wprowadzenia nowych zasad finansowania czasopism, „Rocznik Pedagogiczny" stracił finansowe wsparcie. Redaktorzy nadzieje wiązali $\mathrm{z}$ tomem 41. W zapowiedziach miał być kontynuacją wcześniej podjętych wątków.

Tom 41. ukazał się. We wszystkich działach znalazły się niezwykle ciekawe teksty, a w jednym z nich - Z żałobnej karty - przekazane informacje nieodwołanie wpłynęły na przyszłość. Nie żyje wieloletnia Redaktorka „Rocznika Pedagogicznego”, prof. Maria Dudzikowa. W obliczu tej próby pozostałym członkom Redakcji przyszło zmagać się z własną gotowością do dalszej drogi redakcyjnej.

Z tego, co napisano po Jej śmierci, najbliższe są mi słowa prof. Bogusława Śliwerskiego: „Niewiele jest w uniwersytetach osób, które całym życiem służą innym, które z wyjątkową pasją i niewiarygodną pracą nad sobą, traktują rodzinne, akademickie i społeczne role jako imperatyw moralny". Dla mnie prof. Maria Dudzikowa - Konstruktorka Dróg Życiowych - wydawała się wieczna w swoich zmaganiach o kształt każdej z nich. Pozostaje mi myślenie o Jej śmierci jak o przeprowadzce - z Lodowej pod inny adres, gdzie już nie boli, jest dużo książek, notatników i pięknych korali. 
$\mathrm{W}$ postawie gotowości do działania, przekraczania barier narzuconych przez rzeczywiste doświadczenia, naoczność życiową, w roli recenzenta tomu, zmierzyłam się z tekstami, które przywoływały wspomnienia wątków wielokrotnie podejmowanych na Letnich Szkołach, których prof. Maria Dudzikowa była wieloletnim kierownikiem naukowym.

Tematyka tekstów z działu „Artykuły”, zogniskowana została wokół dwóch kategorii: DOMINACJA i WYZWOLENIE. Opis z ich perspektywy umożliwił wykazanie zawartych w dyskursie edukacyjnym znaczeń i wartości, które zostały określone bez udziału odpowiedzialnych za kształt edukacji podmiotów, a więc narzucone bądź wyretuszowane, ustalone z pominięciem rzeczywistego, niezmitologizowanego kontekstu. Rozpoznanie białych plam, czyli wątków, które zostały wykluczone i zniknęły z całego obszaru oddziaływań szkoły, służy ujawnieniu tego, co negatywne w praktyce edukacyjnej, sprzyja dopełnieniu pola dyskursu o konotacje ideologiczno-polityczne kultury szkolnej. Szczególnie wartościowy jest w tym kontekście tekst Makropolityczne uwarunkowania kultury szkolnej. Autor trafnie opisuje strategie uwikłania kultury szkoły w centralistyczną politykę oświatową, którą prowadzą wszystkie, kolejno zmieniające się rządy wraz z reformą ustrojową w 1999 roku. Obecna w życiu społecznym opcja ideologiczno-polityczna ogranicza lub wyklucza wprowadzenie innowacji w skali mikro. „Przez dziesiątki lat ukształtowało się w polskim szkolnictwie przekonanie, że kończą się one zazwyczaj niepowodzeniem z powodu braku wsparcia i zainteresowania ze strony nauczycieli, kontynuujących edukację $\mathrm{z}$ absolwentami danego cyklu kształcenia. Ten mit nie służy wyzwalaniu nauczycieli z gorsetu obowiązujących jako jedynie słuszne rozwiązań dydaktycznych". Tekst demaskuje krzyczącą nierównowagę między charakterem współczesnej kultury a obrazem świata aplikowanym przez szkołę z innowacyjnością, zazwyczaj pozostającą na poziomie postulatów i deklaracji.

Inną przyczyną nieprzystawalności edukacji do jej rzeczywistych zadań jest, jak przenikliwie diagnozują autorzy dwóch tekstów: Pasja i tożsamość naukowca oraz Scholar in the spectacle of parametrization - between authenticity and game of appearances, zachowawczy stan świadomości pedagogicznego establishmentu, sprowokowany dominującą rolą zewnętrznej motywacji, a w szczególności: komercjalizacją badań naukowych, wskaźnikowaniem pracy naukowców (jako członków „społeczności statystycznej”), wszechogarniającą biurokracją oraz jurydyzacją życia naukowego. Wiedza zredukowana do towaru, przesycenie władzą klasyfikowania i kategoryzowania instytucji i osób w zredukowane do statystycznych schematów segmenty oraz wszechobecna „ideologia rywalizacji”, powodują erozję nauczycielskiej innowacyjności. W kontekście tych refleksji rodzi się pytanie: czy wzmacnianie motywacji 
zewnętrznej stwarza szanse na wyjście poza granice sparametryzowanego świata, który zaczęliśmy akceptować i w którym zaczęliśmy grać nasze role?

Sztuczność, zwłaszcza organizacyjne odizolowanie od intensywności świata pozauczelnianego, inercyjne pozostawanie w strategiach działania nieadekwatnych do złożoności życiowych problemów i niejednoznaczności aksjologicznej, czynią edukację publiczną ułomną, a co gorsza, generującą równie ułomne, upraszczające postrzeganie świata. Podejmując wątek edukacji publicznej, autor tekstu Przegrana szansa edukacji publicznej. Fatalne dziedzictwo, iskry nadziei, rozpoznaje ją jako ogół wpływów - bezpośrednich i pośredniczonych przez wszelkie media - na przeżycia młodych i dorosłych członków społeczeństwa, mających znaczenie dla ich postaw izachowań. Dokonując diagnozy głębokiego kryzysu edukacji publicznej, przenikliwie opisuje „wiekuiste jady polskiego zastoju rozwojowego”: postawę przetrwania własnego i najbliższych za wszelką cenę, spektakularną pryncypialność, instrumentalność, pomieszanie autentyzmu inieautentyczności. Trening mentalny - narzucony, ale też oportunistycznie podejmowany przez uczestników edukacji publicznej ogranicza poczucie odpowiedzialności za własny rozwój i potrzebę twórczego uczestnictwa w życiu wspólnoty. Wyuczone zachowania kształtują ludzi o umysłach i postawach zewnątrzsterownych, podatnych na wszelkie manipulacje i bezkrytycznych wobec światopoglądowych stereotypów.

Opisanie procesów, które w zawrotnym tempie drążą współczesną edukację publiczną bądź tylko sporządzenie listy cech charakteryzujących te procesy, prowadziłoby do nieodkrywczych stwierdzeń. W tekstach autorzy rozważają, co począć z bagażem problemów, które dyskurs edukacyjny będzie musiał dźwignąć. Bez rozpoznania trudności nie sposób określić kierunku poszukiwań ani wykonać jakiegokolwiek odpowiedzialnego ruchu zmierzającego ku rzeczywistej, istotnej zmianie rzeczywistości edukacyjnej. Zasadne są więc pytania o środki zaradcze dla współczesnej edukacji.

W tak złożonym systemie wielorakich uwikłań niemożliwe jest przekształcenie radykalne. Ale na pewno możliwe jest uruchomienie namysłu nad kategorią WYZWOLENIA za sprawą Freirowskiej „edukacji budzącej świadomość” oraz Habermasowskiej edukacji zorganizowanej wokół idei emancypacji. Opis „edukacji wyzwalającej świadomość” uobecnia się w wątkach wybranych tekstów: powrotu do ruchu mikroinnowacji antysystemowych (Makropolityczne uwarunkowania kultury szkolnej) oraz ruchu uspołeczniania edukacji szkolnej (Terenowe rady oświatowe w procesie uspołecznienia edukacji szkolnej), stworzenia dogodnego klimatu do uobecnienia się „tożsamości akademickiej” (Pasja i tożsamość naukowca), czy zaktywizowania 
myślenia wspólnotowego (Przegrana szansa edukacji publicznej. Fatalne dziedzictwo, iskry nadziei).

Sprawą największej wagi jest zminimalizowanie siły czynnika inercyjnego, który można by określić jako błogostan odgradzający od przemian ogólnokulturowych. Długotrwałe złudzenie, że szkoła miękko zaadaptuje się do zjawisk zachodzących w kulturze bez dogłębnych przekształceń w sferze koncepcji edukacji, czyni ją miejscem, w którym odbywa się swoisty trening bezdusznej rywalizacji oraz bezkrytycznie akceptuje się płytki indywidualizm. Tymczasem wyzwaniem współczesności okazuje się wspólnotowość i solidarność ( $w$ miejsce egoistycznego wyścigu po sukces), twórcza oryginalność (w miejsce unifikacji), otwartość i empatia (zamiast bezrefleksyjnie przejmowanych uprzedzeń, stereotypów i bezlitosnego wykluczania). Zdaniem autora tekstu Przegrana szansa edukacji publicznej. Fatalne dziedzictwo, iskry nadziei, szczególnego znaczenia nabierają: (1) „uspołecznienie, wspólnotowość, zaufanie, życzliwość, przyjaźń i miłość, wyzbywanie się negatywnych emocji, takich jak zawiść, nienawiść; (2) dojrzałość moralna, uwewnętrznienie uniwersalnych zasad etycznych i konsekwencja w ich przestrzeganiu, przeciwdziałanie »brudnym wspólnotom « w każdej skali; (3) silna osobowość, bogata w życie wewnętrzne tożsamość, zdolność do głębokich przeżyć, duchowość, wierność sobie; (4) aktywność, powaga i odwaga podejmowania zadań życiowych, odpowiedzialność za siebie i za dobro wspólne społeczności i społeczeństwa narodowego i globalnego". Jest w tej diagnozie wyraźna sugestia, że szkoła powinna konstruktywnie i wyprzedzająco wyartykułować swoją rolę w rzeczywistości teraźniejszej i przyszłej. Wspierać „dzieci i młodzież w uczeniu się samodzielnego i krytycznego czytania świata oraz opanowywania "sztuki tworzenia samego siebie«" (M. Dudzikowa).

Rozwiązaniem może być powrót do ruchu mikroinnowacji antysystemowych w szkolnictwie publicznym (wewnątrzszkolnych mikrokultur), które przywracają zarazem poczucie godności i samorealizacji zawodowej nauczycieli. Przenikanie do szkolnictwa publicznego innowacyjnych wzorów zmiany w kształceniu i wychowaniu może dokonywać się za sprawą pojedynczych nowatorów (transformacyjnych liderów), autorskich inicjatyw społeczników (rodziców, stowarzyszeń, wspólnot) czy naukowców. Są to wówczas innowacje wdrażane przez indukcję, wzbudzane oddolnie, umożliwiające rzeczywiste przenikanie nowych, alternatywnych rozwiązań cząstkowych lub całościowych w zakresie kształcenia dzieci czy młodzieży (Makropolityczne uwarunkowania kultury szkolnej). Wsparciem dla tej inicjatywy mogą być terenowe rady oświatowe, które w procesie uspołecznienia polskiej oświaty, pomimo 
możliwości gwarantowanych przez prawo, w praktyce nadal są rzadkością (Terenowe rady oświatowe w procesie uspołecznienia edukacji szkolnej).

Myślenie o interakcjach w dyskursie edukacyjnym prowadzi do następujących refleksji: jeśli edukacja zarówno kształtuje ludzki umysł, jak i umożliwia jego funkcjonowanie, to trzeba przyjąć, że uczenie się i myślenie sytuują się w środowisku kulturowym, a wartość edukacji jest pochodną wykorzystania jego zasobów. Więcej, nawet różnice indywidualne, zależne zasadniczo od natury i funkcjonowania umysłu, można przypisać rozmaitości okazji dostarczanych przez różne środowiska kulturowe. Wątek ten podejmują autorki dwóch tekstów: Kultura szkoły w rozumieniu deskryptywnym i normatywnym. Wybrane egzemplifikacje oraz Kultura emocjonalna. W poszukiwaniu nowych ujęć praktyki szkolnej. Trzeba więc, podejmując wysiłek przebudowy szkoły, myśleć o obszernym, wielowymiarowym kontekście i tle - o „kulturze edukacji”. Jest ona bowiem szeroko pojętym zespołem uwarunkowań przesądzających o wartości edukacji. Takie myślenie wymaga jednak odrzucenia wielu stereotypów, na których ugruntowana jest kultura edukacji i poszukiwania dla szkoły nowych źródeł inspiracji, innych niż te, które projektują i sankcjonują edukację nacechowaną pedagogicznym redukcjonizmem.

Ważnych rozwiązań w zakresie zmiany „kultury edukacji” dostarczają teksty z działu „Edukacja w świecie - studia porównawcze”. W podjętej próbie zrekonstruowania aktualnych problemów edukacyjnych w perspektywie porównawczej autorzy pięciu tekstów: (1) „Nauczyciel największa wartościa naszego narodu” - retoryka, praktyka i skutki "reformy” kształcenia nauczycieli w Anglii i Walii; (2) Edukacja pod baobabem. O reformowaniu szkolnictwa $w$ Republice Kenii; (3) From dialogue to a training field. The next challenge of professional learning of novice school principals in Israel; (4) Attitudes of teachers in the Arab schools in Israel towards integration of students with special needs; (5) Meaningful Learning: The Main Constitutive and Consecutive Components and their Presence in Science Teaching, stawiają pytania o sposób organizowania edukacji w Polsce i w innych krajach.

Przyjęta perspektywa pozwala skonfrontować ustalone sposoby myślenia o edukowaniu dzieci z zupełnie odmiennymi rozwiązaniami. Może przyczynić się też do określenia na nowo zamierzeń polskiej szkoły, a także zarysowania szerokiego i wielowymiarowego kontekstu przesądzającego o wartości edukacji publicznej. Spotkanie z odmiennością edukacyjnych rozwiązań pozwala skonfrontować iluzoryczną adekwatność oddziaływań polskiej edukacji z realnymi wyzwaniami współczesności i przewidywanymi kierunkami jej przeobrażeń. Z diagnoz wynika, że wobliczu zmiennych przeobrażeń cywilizacyjnych polska szkoła wymaga głębokiego przedefi- 
niowania zobowiązań wobec przyszłości. Najistotniejszy aspekt koniecznych przekształceń dotyczy nie tylko systemu edukacji, artykułowanych oficjalnie i nieartykułowanych otwarcie celów, ale strategii, która złagodziłaby napięcia między utrwalonym modelem kształcenia a zjawiskami rodzącymi się w polifonicznej sferze różnorodnych, często sprzecznych oddziaływań, otaczających zewsząd ucznia. Dostrzeżenia, że edukacja ma wymiar nie tylko wąsko pragmatyczny - wytyczony przez horyzont mierzalnych osiągnięć, egzaminów. Proces nadawania nowego kierunku zmianom edukacyjnym dotyczy warunków do uruchamiania zindywidualizowanych znaczeń, ale także aktywnej współpracy z dziećmi, polegającej na udzielaniu im wsparcia przez kompetentnego nauczyciela („Nauczyciel największa wartościa naszego narodu” - retoryka, praktyka i skutki "reformy” kształcenia nauczycieli w Anglii $i$ Walii).

Zainteresowanie edukacją publiczną $\mathrm{w}$ różnych kontekstach nie ma prostych odniesień do zagadnień podejmowanych w tradycji badań pedagogicznych, o czym zaświadczają teksty zamieszczone w dziale: Metodologia i doniesienia $\mathrm{z}$ badań (proponuję zamianę kolejności tekstu piątego z szóstym). Dostarczają instrumentarium adekwatnego do metodologicznych ujęć dynamicznych zjawisk, jakimi są: (1) rzeczywistość szkolna (Jak badać szkołę? Przykłady zastosowania badań jakościowych i mieszanych wanalizie i interpretacji rzeczywistości szkolnej na tle dyskusji dotyczacej strategii badawczych); (2) codzienny czas szkolny nauczycieli (Badanie codziennego czasu szkolnego nauczycieli - namysł nad własna praktyka badań fenomenograficznych); (3) wspólnotowość hybrydowa (Wspólnotowość hybrydowa jako kategoria w oglądzie grup studenckich. Próba wykorzystania); (4) proces infantylizacji wedukacji wyższej (Poza infantylizacje wedukacji wyższej. Przygotowanie studentów do życia w (nie)bezpiecznym społeczeństwie); (5) proces przejścia młodzieży szkolnej z gimnazjum do szkoły ponadgimnazjalnej z wykorzystaniem kategorii rytuału przejścia (Postrzeganie siebie jako człowieka i jako ucznia przez gimnazjalistów i gimnazjalistki u progu przejścia do szkoły średniej. Doniesienie z badań); (6) Po doświadczeniach pisania pracy magisterskiej w obliczu pracy nad rozprawa doktorska. Esej o moich zmaganiach $z$ warsztatem badawczym.

Autor pierwszego tekstu badania jakościowe oraz ilościowe przypisuje do przeciwstawnych stanowisk filozoficzno-teoretycznych, obejmujących odmienną ontologiczną i teoriopoznawczą wizję świata. Dokonując szczegółowej analizy wybranych obszarów problemowych szuka uzasadnienia dla mieszanych strategii postępowania badawczego, które determinują: problematyka i cel, przedmiot i zasięg analizy oraz doświadczenia badacza. 
W dwóch kolejnych tekstach autorzy przyjęli podejście jakościowe, wskazali nowe obszary badawcze i stworzyli podwaliny pod całkowicie odmienne postrzeganie natury zjawisk edukacyjnych: codzienny czas szkolny z perspektywy fenomenograficznej oraz rekonstrukcja formalnie wyznaczonych grup studenckich jako wspólnot hybrydowych. Zrekonstruowane typ, charakter, sposób organizowania badań właściwych podejściu jakościowemu mają szczególne znaczenie w rzeczywistości edukacyjnej, jeśli się ją widzi w całej złożoności i zmienności oddziaływań, skomplikowanych uwikłań i wielowymiarowych skutków, a więc jako pole różnorodnie zdeterminowanych zdarzeń.

$\mathrm{Z}$ namysłu nad problemem infantylizacji w edukacji wyższej w tekście czwartym zrodził się teoretyczny cel badań demaskujących mechanizmy powodujące infantylizację studentów. Autor stawia tezę, że współczesna edukacja na poziomie wyższym nie przygotowuje studentów do rozwijania krytycznego myślenia oraz nie wyposaża w umiejętności radzenia sobie z sytuacjami problemowymi, typowymi dla społeczeństwa globalnego. W zamian za to aprobuje i wdraża mechanizmy prowadzące do zdziecinnienia dorosłych ludzi, którymi są: cenzura, przestrogi, medykalizacja języka oraz mikroagresja. W tekście autor analizuje te niebezpieczne zjawiska oraz wskazuje na konsekwencje, jakie ze sobą niosą nie tylko dla rozwoju uniwersytetu jako instytucji, ale przede wszystkim jego podmiotów.

W podjętej próbie zdiagnozowania przebiegu przejścia młodzieży szkolnej z gimnazjum do szkoły ponadgimnazjalnej, z wykorzystaniem kategorii rytuału przejścia, autor piątego tekstu bardzo klarownie opisuje dwuletnie badania panelowe. Określa przebieg i wyprowadza profile przejścia z gimnazjum do szkoły średniej, zdeterminowane wybranymi grupami czynników: "Ja” w oczach innych (w roli kolegi i ucznia); stosunek emocjonalny do szkoły; poziom identyfikacji ze szkołą; orientacja temporalna; stopień sprecyzowania planów edukacyjnych na przyszłość; stosunek do zmiany. Ważną rolę w procesie identyfikowania profilów przejścia odgrywały także czynniki związane $\mathrm{z}$ osobą badanego, z jego środowiskiem rodzinnym oraz szkolnym.

Całość tomu zamyka tekst młodego badacza, który dzieli się doświadczeniami związanymi z pisaniem pracy magisterskiej i projektowaniem badań do dysertacji doktorskiej. W tekście wskazuje determinanty, które podczas prowadzenia projektów badawczych kształtowały jego dojrzałość badawczą.

Reasumując, recenzowany tom ma ogromne walory poznawcze i praktyczne. Stanowi przykład bardzo udanych nowatorskich poszukiwań badawczych. Doskonale dobrane teksty nie zamykają podjętych wątków badawczych, lecz otwierają przestrzeń dla nowych pytań o szkołę i jej edukacyjną ofertę. 


\section{SUMMARY}

"Pedagogical Yearbook" review, vol. 41

ed. by Maria Dudzikowa

The text is a presentation of one of the volumes of "Pedagogical Yearbook", a scientific journal that is significant in showing current pedagogical problems.

KEY WORDS: pedagogy, "Pedagogical Yearbook", liberation, culture of education 